\title{
Patterns in Kindergarten: Teachers' Knowledge of Content and Pupils and Associated Self-Efficacy Beliefs
}

\author{
Vzory ve školce: Didaktické znalosti týkající se obsahu a žáků a související \\ přesvědčení
}

\author{
Iris Schreiber ${ }^{1}$ \\ ${ }^{1}$ Kibbutzim College of Education, Bar-Ilan university, Israel; irisifi5@gmail.com
}

The present study investigates sixty Israeli kindergarten teachers and examines two aspects that might affect the teaching-learning process of patterns: Teachers' pedagogical knowledge of content and pupils (specifically, what is easy or difficult for the children and what their typical errors are) and teachers' self-efficacy, particularly with regard to their knowledge. These aspects are explored via two types of patterns a repeating pattern and a growing pattern, and by comparing two teacher groups novice teachers and experienced teachers. The results regarding the repeating pattern show that teachers have knowledge of children's typical errors. However, they only have partial knowledge of what is easy or difficult for the children: they tend to underestimate children's abilities. Regarding the growing pattern, teachers only have a partial knowledge of children's typical errors. Also, they cannot fully discern what the pupils find easy or difficult: they tend to overestimate children's abilities. Using teachers' seniority as a criterion, novice teachers were found to be less knowledgeable and less confident (i.e. they have lower self-efficacy). The results may have implications for teachers' education and guidance, especially novice teachers.

Studie se šedesáti učiteli mateřské školy v Izraeli zkoumá dva aspekty, které mohou ovlivnit výuku „vzorů“: Didaktické znalosti týkající se obsahu a žáků (konkrétně co je pro žáky jednoduché a co je obtížné a jaké jsou typické chyby) a učitelovo vnímání vlastní zdatnosti (self-efficacy). Tyto aspekty jsou analyzovány prostřednictvím dvou typů vzorů - opakující se vzor a rostoucí vzor, a porovnáním dvou skupin učitelů začátečníci a zkušení učitelé. Výsledky týkající se opakujícího se vzoru ukazují, že učitelé mají povědomí o typických chybách žáků. Mají ovšem jen částečnou znalost toho, co je pro děti jednoduché a co obtížné. Mají tendenci výkon dětí podceňovat. Co se týče rostoucího vzoru, učitelé mají částečné znalosti typických chyb i toho, co je pro děti jednoduché a co obtížné. Mají tendenci výkon dětí přeceňovat. Co se týče učitelské zkušenosti, začátečníci mají menší důvěru ve vlastní zdatnost a menší znalosti. Výsledky mají důsledky pro vzdělávání učitelů zejména u začátečníků.

Key words:
kindergarten,
mathematics, patterns,
pedagogical-content-
knowledge,
self-efficacy.

Received 7/2019

Revised $10 / 2019$

Accepted 2/2020

\section{Introduction}

It is commonly agreed that mathematics learning in early childhood has a formative effect - it is essential for consolidating the foundations of many topics and concepts that children will learn later on in school (Clements, 2001; National Council of Teachers of Mathematics, 2000). An important topic, which is part of the curriculum in many countries, is patterns. A pattern is a series of elements arranged according to a certain rule. Each element has a single value determined by its place in the series, so that the elements appear in a predictable way. Patterns and structures are considered as the heart of algebraic thinking, which may be promoted by continuing a pattern, being able to describe a 'general' element and expressing and justifying these generalizations (Zazkis \& Liljedahl, 2002; Warren, 2005).

An effective teaching-learning process is impacted by various aspects and the present study focuses on two of them. One aspect is teachers' pedagogical content knowledge which was indicated by many researchers as necessary for effective teaching of mathematics (Ball et al., 2008; National Council of Teachers of Mathematics, 2000; Shulman, 1986, 1987). The present study focuses on a specific pedagogical content knowledge component that has not been investigated enough regarding patterns: knowledge of content and students, which is the integration of subject-matter knowledge with an acquaintance of students. This kind of knowledge may improve the quality and precision of the teaching process. Teachers who are aware of student's concepts and difficulties can plan their teaching better. The second aspect investigated in this study is teachers' self-efficacy which was defined by Bandura (1977) as one's belief in one's ability to organize and execute a series of actions required for achieving a certain desired result. Self-efficacy is important because teachers' performance in class may be impacted by their confidence in their ability to successfully perform certain teaching processes (Dellinger et al., 2008). These aspects were examined in Israel by a comparison of two kindergarten teacher groups, 30 novices and 30 experienced. 


\section{Literature review}

\subsection{Mathematics and patterns in kindergarten}

During the last decade, educators have acknowledged the importance of promoting children's mathematics knowledge already from an early age. The significance of mathematics learning for developing creativity, mathematical skills, and thinking abilities is emphasized in standard documents and in various curricula (Ministry of Education in Israel, 2010; NCTM, 2000). Researchers have frequently discussed mathematics curricula at pre-school ages, recommending many learning activities that may promote mathematical thinking (Clements, 2001; Clements \& Sarama, 2007, 2011; Greenes et al., 2004).

The present study focuses on the mathematical topic of patterns, which is part of the mathematics curriculum for kindergartens in many countries, including Israel. Its importance is highlighted in policy documents and curricula: "Patterns are everywhere. Children, who are encouraged to look for patterns and to express them mathematically, begin to understand how mathematics applies to the world in which they live" (NCTM, 1989: p. 60). Patterns may form the basis for understanding recurring structures, which promote the acquisition of various mathematical concepts - such as variables, functions and algebraic expressions (Moss \& Beatty, 2006; Warren, 2005). Patterns may also lead to a high level of thinking the ability to generalize (Ministry of Education in Israel, 2010). Recommendations for early ages suggest focusing on patterns with different characteristics, such as color, position, quantity, sound or movement.

The current research engages in two types of patterns: a repeating pattern and a growing pattern. The difference between the two types of patterns is the way in which their elements are arranged:

$A$ repeating pattern is a pattern in which an element repeats itself systematically and a growing pattern is a pattern that increases or decreases systematically (see examples in Fig. 1).

\section{A repeating pattern 0000000000}

A growing pattern

Fig. 1: Examples of the two pattern types

According to the curriculum of mathematics for kindergarten in Israel, the subject of repeating patterns should be taught first with patterns that have one characteristic, such as color or shape (see examples in Fig. 2), and then patterns that have two characteristics, such as color and quantity or color and shape, which is the type of pattern chosen for the present study (see examples in Fig. 2).

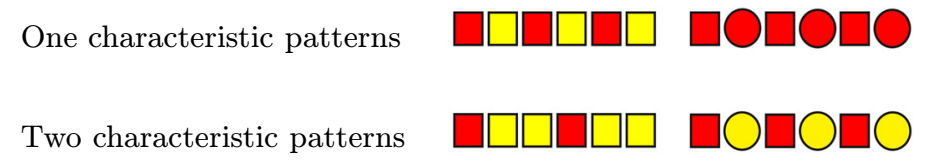

Fig. 2: Examples for repeating patterns characteristics

Growing patterns are not part of the Israeli mathematics curriculum for kindergarten. However, since they are included in the curriculum of other countries and have been investigated, I decided to include a growing pattern in the research. I chose to keep the same characteristics (color and shape) as in the repeating pattern, while adding the growing quantity (see Fig. 3).

The repeating pattern

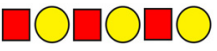

The growing pattern

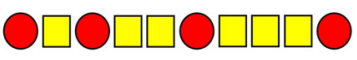

Fig. 3: The patterns chosen for the study

Many studies recommend teaching the topic of repeating and growing patterns at all ages, particularly in kindergarten, and suggest activities and tasks such as describing, creating, continuing or completing a pattern (Burton, 1982; Gibbs, 1999; Threlfall, 1999; Papic \& Mulligan, 2007; Papic et al., 2011; Warren, 2005).

The present study investigates two types of tasks that, according to the curriculum in many countries (including Israel) and to many researchers, are considered ones that may promote mathematical thinking and generalization abilities: 
1. "Continue a pattern": children are asked to produce/create/build a continuation for a given pattern (Burton, 1982; Economopoulos, 1998; Warren, 2005).

2. "Complete a pattern": children are asked to produce/create/build the missing elements of a given pattern (Burton, 1982; Papic \& Mulligan, 2007; Warren, 2005).

The tasks incorporated in this research are: "continue a repeating pattern", "complete a repeating pattern" and "continue a growing pattern".

\subsection{Pedagogical knowledge of content and students}

Lee Shulman $(1986,1987)$, one of the most prominent researchers defining the type of knowledge which teachers need for an effective teaching process, argued that a combination of content knowledge and pedagogical knowledge is necessary. Pedagogical content knowledge integrates them both. Regarding mathematics, it may involve knowledge of various ways of presenting a mathematical idea and knowing to estimate the difficulty levels of specific topics. Such knowledge helps teachers to plan better lessons, to connect ideas and concepts during and between lessons, and to cope with students' difficulties. Past studies show a correlation between teachers' mathematical pedagogical content knowledge and children's improved attainments (McCray \& Chen, 2012) it with the wider the teachers' knowledge was, the more extensive the students' knowledge and the better their attainments were (Tchoshanov, 2011).

A group of researchers led by Deborah Ball (Ball et al., 2008; Hill et al., 2008) defined more specifically the term pedagogical content knowledge in mathematics education, attributing two aspects to it. The first is Knowledge of Content and Teaching which includes, for example, assessing the strengths and weaknesses of different tasks, knowing what examples are suitable for presenting a certain topic and which examples should be used to enhance knowledge. The second aspect, on which this study focuses, is Knowledge of Content and Students. It includes, for example, identifying what is easy or difficult for specific groups of students, finding what their common errors are and possible reasons thereof. Knowledge of content and students is important for the teaching-learning process because it enables teachers to focus their explanations and give students a variety of effective tasks.

Studies of patterns in kindergarten, which explored different aspects of teachers' knowledge, show that teachers have partial pedagogical content knowledge. On the one hand, they know how to solve patterning tasks, describe patterns and notice errors children make. On the other, they are not familiar with various tasks, with the way children think or with what should be done in order to promote children's knowledge (Economopoulos, 1998; Fox, 2005b; Waters, 2007; Zhang, 2015). Based on the theory conceived by Ball (Ball et al., 2008), Lee (2010) examined preschool teachers' mathematical pedagogical content knowledge in various topics. In the case of patterns, the researcher found that teachers possessed a high level of knowledge of how to teach patterns. However, Lee's study did not examine teachers' patterning knowledge of content and students and in general, this aspect has not been sufficiently investigated regarding patterns. Therefore, I have decided to study this specific component of knowledge.

The present study examined teachers' patterning knowledge of content and students in two aspects: what the children's common errors are and what is easy or difficult for them. Regarding children's errors, studies indicate wrong answers for patterning tasks that children frequently give. For example: continuing a pattern randomly (Clements \& Sarama, 2007; Starkey et al., 2004); repeating one element of the pattern systematically (Clements \& Sarama, 2007; Starkey et al., 2004); and copying the pattern like a mirror image (Fox, 2005a; Garrick et al., 1999).

Regarding what is easy or difficult for children, the literature indicates the basic unit and its length as the most prominent factors determining the difficulty level (Kyriakides \& Gagatsis, 2003; Threlfall, 1999). Moreover, findings illustrate that growing patterns are more difficult for children than repeating patterns (Warren, 2005). The results of studies that examined the differences between continuing and completing repeating patterns were inconclusive (Warren, 2005; Warren \& Miller, 2010).

In the present study, when indicating what is easy or difficult for children, the teachers were also asked to refer to differences between older and younger children. Studies show that older children succeed more than younger children even with no teaching process (Mulligan et al., 2004).

\subsection{Self-efficacy}

Self-efficacy is one's assessment of one's ability to successfully perform a certain task (Bandura, 1977; 1986). Bandura defined self-efficacy as "people's judgments of their capabilities to organize and execute a course of action required to attain designated types of performances" (1986, p. 391). Hackett and Betz (1989) defined mathematical self-efficacy as "assessment of an individual's confidence in her or his ability to successfully perform or accomplish a particular task or problem" (p. 262). This study explores teachers' 
pedagogical-mathematical self-efficacy, i.e. their confidence in their pedagogical knowledge. Self-efficacy connects performance and confidence: in order to complete a task effectively, people need both the suitable skills and the confidence in their ability to apply them as required (Dellinger et al., 2008). The level of self-efficacy has a direct impact on people's choices and behavior: people act with confidence in situations whereby they believe they may function well, but they tend to avoid situations in which they don't believe in their abilities or knowledge. Furthermore, self-efficacy affects the amount of time and effort people invest in performing certain tasks: the higher one's self-efficacy level is, the more persistent in completing a task one is. Studies found that self-efficacy may significantly impact teachers' performance (Dellinger et al., 2008) and is related to their behavior in the classroom and to students' results (Midgley et al., 1989). Teachers whose level of self-efficacy was high had greater job satisfaction, were more involved in the preparation of personal curricula for the students and cooperated better with parents and colleagues (Brouwers \& Tomic, 2000).

A sense of self-efficacy is examined with respect to a specific subject. The present study examined kindergarten teachers' self-efficacy in pedagogical knowledge of content and students related to the topic of patterns, which has not been sufficiently investigated.

\subsection{Teachers' seniority}

In the present study, teachers' knowledge and self-efficacy were investigated and compared between two teacher groups: novice and experienced.

Studies of teachers' professional development (Ball \& Wilson, 1990; Leinhardt, 1989; Tirosh et al., 1998; Zhang, 2015) refer to novice teachers as teachers with seniority of up to five years, and experienced teachers as teachers with seniority of at least ten years. The present study adheres to these definitions. These studies compared mathematical knowledge of novice and experienced teachers in elementary and high schools and found that experienced teachers had a broader pedagogical knowledge than novice teachers. However, other researchers did not find a positive correlation between seniority and different types of knowledge (Krauss et al., 2008).

Regarding self-efficacy and seniority, the literature presents inconsistent findings. Chiu and Klassen (2010) found a connection between teachers' years of experience and their self-efficacy. In a study conducted by Tschannen and Woolfolk (2007), experienced teachers rated themselves higher on overall selfefficacy than novice teachers, but on some specific aspects, there was no significant difference between the two groups. Another study showed that teachers' experience was not associated with their self-efficacy (Guo et al., 2011).

\section{Research aims}

The first aim of the study is to explore teachers' knowledge of content and students related to patterns: Do teachers know which type of pattern and which patterning tasks are easier for students and which are more difficult? Do teachers know students' common errors in the patterning tasks? Is there a difference between the knowledge demonstrated by novice teachers and the knowledge demonstrated by experienced teachers?

I hypothesized that novice teachers would have less knowledge of content and students based on past findings (e.g. Tirosh et al., 1998) and on the fact that they are not acquainted enough with students' conceptions and misconceptions.

The second aim of the present study is to explore teachers' level of self-efficacy related to their knowledge: What is the teachers' level of self-efficacy in their pedagogical knowledge of content and students (i.e., what is the teachers' level of confidence regarding their knowledge)? Is there a correlation between teachers' level of confidence and teachers' seniority?

I hypothesized that novice teachers are less confident in their knowledge due to the findings of previous studies (e.g. Chiu \& Klassen, 2010).

\section{Methodology}

The present study was conducted in two stages, the first with children and the second (on which this paper focuses) with teachers. 


\subsection{The first stage of the study}

The first stage, the "preliminary study", examined children's knowledge of patterns. The participants were 206 Israeli children: 99 children aged $4-5$ and 107 children aged 5-6. All the children attended kindergartens in the same region of Israel and had the same socioeconomic status (as determined by the Ministry of Education in Israel). Each kindergarten comprised about 30 children, aged 4-6. For the children aged 4-5, it was the first year at kindergarten, and for the children aged 5-6, it was the second year at kindergarten. Ethical approval was given by the Chief Scientist of the Ministry of Education in Israel.

The two patterns that were chosen for this study (see Fig. 3) were incorporated into three tasks (see Fig. 4): continuing a repeating pattern, completing a repeating pattern, continuing a growing pattern.

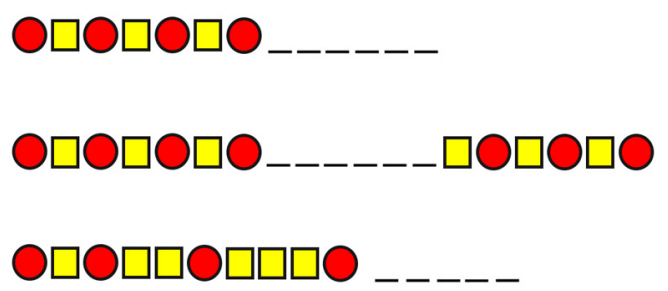

Fig. 4: The examined three tasks

The children answered the three tasks in front of a computer screen, using a software developed specifically for the study. Each child responded to the questionnaire in the presence of the researcher in a quiet area of the kindergarten. The children's responses (the way they continued or completed the pattern and their oral response) were documented and recorded.

It is noteworthy that the kindergartens in which the preliminary study was conducted were mainstream education kindergartens without special education children or under-achievers. Before answering the questionnaire, the children practiced, played and became familiar with the software, learning how to move the shapes to the appropriate place.

The aim of the first stage is to examine the patterning knowledge of preschool children:

How do kindergarten children respond to the three patterning tasks, regarding the percentage of correct answers and common errors (see the expected answers in Fig. 5)? Is there a difference between the knowledge demonstrated by younger children and the knowledge demonstrated by older children?

I hypothesized that older children would respond more correctly than younger children due to their longer studying term in kindergarten and based on past findings (e.g. Mulligan et al., 2004).

\section{Оㅇ०ㅇㅁ므므므믕}

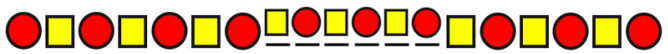

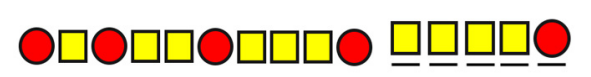

Fig. 5: The expected correct answers for the three tasks

\subsection{The second stage of the study}

At the second stage, in which this paper engages, the participants were 60 kindergarten teachers: 30 novice teachers, whose seniority was up to 5 years, and 30 experienced teachers, whose seniority was 10 years or more. All the teachers are females, have a first degree in education and they were trained to teach and work in mainstream education kindergartens. The teachers work in the same kindergartens in which the preliminary study was conducted.

The research instruments were two questionnaires, a Knowledge Questionnaire, and a Self-Efficacy Questionnaire, that were validated by three mathematics teaching experts.

The questionnaires related to the three tasks that the children had answered in the preliminary study. Reliability was examined with 10 teachers. A Cronbach's coefficient alpha was calculated, using the pilot data. The reliability score ( $>0.7)$ of the instruments had an acceptable level of reliability.

The teachers' self-efficacy questionnaire consisted of an Attitudes Scale, in which the teachers were asked to point out the level of confidence in their ability to predict children's typical errors and the level 
of confidence in their ability to estimate children's percentage of success in each of the three tasks that the children had answered in the preliminary study ("Continue a repeating pattern", "complete a repeating pattern", "continue a growing pattern"). They ranked their confidence in their ability from 1 (not at all confident I can), through intermediate degrees of confidence (3 - moderately confident I can), to complete confidence (5 - very confident I can).

The teachers responded to the questionnaire examining pedagogical knowledge after they had responded to the self-efficacy questionnaire. They were asked to estimate the percentage of success of children, as well as indicate the errors that children would make in each task.

\subsection{Data analysis}

The preliminary study examined children's knowledge and provided two sets of data. The first consisted of children's responses to the three patterning tasks - these responses were either correct or incorrect. The percentage of correct answers was calculated for each group of children separately and for them all. The second set of data was an analysis of the incorrect answers: was the error observed in previous studies and what was the percentage of children that made that error.

In the second stage, as related above, the self-efficacy statements were given a score from 1-5. A Pearson correlation test was taken to examine whether there is a correlation between teachers' confidence scores and years of experience.

Regarding teachers' knowledge of content and students (specifically what is easy or difficult for children), the teachers were asked to estimate the percentage of success of children. The teachers' answers regarding the percentage of success are organized in ranges of $20 \%$ as follows:

- between $0 \%-20 \%$ - almost none of the children would answer correctly,

- between $21 \%-40 \%$ - a minority of the children would answer correctly,

- between $41 \%-60 \%$ - about half of the children would answer correctly,

- between $61 \%-80 \%$ - most children would answer correctly,

- between $81 \%-100 \%$ - almost all the children would answer correctly.

A T-test was taken to examine the difference between the two teacher groups. The mean estimation was calculated, and the teachers' estimation was compared with the children's findings in the preliminary study.

Regarding teachers' knowledge of content and students (specifically what were the common errors the children made), the teachers were asked to indicate errors that children would make in each task. The errors the teachers noted were compared with known errors from previous studies and with the findings of the preliminary study. A chi-square test was taken to examine the difference between the two teacher groups.

\section{Results}

\subsection{Overview}

Levels of self-efficacy regarding knowledge of children's errors and knowledge of percentage of success were similar: $\sim 70 \%$ of the teachers were confident about the "continue a repeating pattern" task and $\sim 50 \%$ of the teachers were confident about the two other tasks.

Results regarding pedagogical knowledge were inconclusive: Regarding children's errors, the teachers mentioned some of the errors that the children had made, but they also mentioned errors that the children had not made and failed to mention the most common error (copying the pattern). Regarding the difference between children aged 5-6 and children aged 4-5 (see Tab. 1), teachers estimated that children aged 5-6 would answer the tasks more correctly than children aged 4-5 (93\% of the teachers). Their estimation was correct only regarding the "continue a repeating pattern" task. Regarding children's success, teachers either underestimated or overestimated children's performance, as demonstrated in Tab. 1.

Tab. 1 illustrates that teachers estimated correctly that the growing pattern task is more difficult for children than the repeating pattern tasks, but that they also estimated incorrectly that completing a repeating pattern is more difficult than continuing a repeating pattern. Tab. 1 also demonstrates that in the cases in which the teachers were incorrect, the gap between their estimation and the children's actual success percentage as well as the variance of the findings were greater (see sd value in Tab. 1). 
Tab. 1: A comparison between the percentage of success that the teachers estimated and the actual percentage of success of the children

\begin{tabular}{|c|c|c|c|c|c|c|}
\hline & \multicolumn{3}{|c|}{ Children aged 5-6 } & \multicolumn{3}{|c|}{ Children aged $4-5$} \\
\hline & $\begin{array}{c}\text { Teachers' } \\
\text { estimation } \\
\text { M (SD) }\end{array}$ & $\begin{array}{l}\text { Children's } \\
\text { success }\end{array}$ & $\begin{array}{c}\text { Difference } \\
\text { (t-value) }\end{array}$ & $\begin{array}{c}\text { Teachers' } \\
\text { estimation } \\
\text { M (SD) }\end{array}$ & $\begin{array}{l}\text { Children's } \\
\text { success }\end{array}$ & $\begin{array}{c}\text { Difference } \\
\text { (t-value) }\end{array}$ \\
\hline Continue a repeating pattern & $\begin{array}{c}89.3 \\
(10.2)\end{array}$ & 88.8 & 0.34 & $\begin{array}{c}69.0 \\
(18.0)\end{array}$ & 71.0 & -1.17 \\
\hline Complete a repeating pattern & $\begin{array}{c}80.3 \\
(18.2)\end{array}$ & 94.4 & $-6.00 * *$ & $\begin{array}{c}60.0 \\
(22.3)\end{array}$ & 77.8 & $-6.17^{* *}$ \\
\hline Continue a growing pattern & $\begin{array}{c}38.1 \\
(21.4)\end{array}$ & 7.5 & $11.11^{* *}$ & $\begin{array}{c}13.2 \\
(14.4) \\
\end{array}$ & 3.0 & $5.44^{* *}$ \\
\hline
\end{tabular}

Note. ${ }^{* *}=p<0.01$

\subsection{Results of teachers' self-efficacy}

The self-efficacy questionnaire explored the teachers' level of confidence in their pedagogical knowledge of content and students. Specifically, the teachers were asked to rank their level of confidence in predicting children's errors as well as children's percentage of success in patterning tasks, on a scale of 1-5 (5 - very confident, 1 - not at all confident).

A positive correlation was found between the teachers' seniority and their confidence in their ability to predict children's errors $(r=0.38, t=3.134, p<0.05)$. Similarly, a positive correlation was found between the teachers' seniority and their level of confidence in their ability to predict children's percentage of success $(r=0.29, t=2.26, p<0.05)$. Thus, the more seniority teachers have, the more confident they are in their ability to predict children's errors as well as what is easy or difficult for them in patterning tasks.

In general, the teachers' scored their confidence high. Tab. 2 presents the mean score of self-efficacy for every component of knowledge, in every task and in each group.

Tab. 2: Mean self-efficacy score and standard deviation in every area of knowledge for every task

\begin{tabular}{|c|c|c|c|c|c|c|}
\hline & \multicolumn{3}{|c|}{$\begin{array}{c}\text { level of confidence in predicting } \\
\text { children's errors }\end{array}$} & \multicolumn{3}{|c|}{$\begin{array}{l}\text { level of confidence in predicting } \\
\text { children's percentage of success }\end{array}$} \\
\hline & $\begin{array}{c}\text { Continue } \\
\text { a repeating } \\
\text { pattern } \\
M(\mathrm{sd})\end{array}$ & $\begin{array}{c}\text { Complete } \\
\text { a repeating } \\
\text { pattern } \\
\mathrm{M}(\mathrm{sd})\end{array}$ & $\begin{array}{c}\text { Continue } \\
\text { a growing } \\
\text { pattern } \\
M(\mathrm{sd})\end{array}$ & $\begin{array}{l}\text { Continue } \\
\text { a repeating } \\
\text { pattern } \\
\mathrm{M}(\mathrm{sd})\end{array}$ & $\begin{array}{c}\text { Complete } \\
\text { a repeating } \\
\text { pattern } \\
M(\mathrm{sd})\end{array}$ & $\begin{array}{c}\text { Continue } \\
\text { a growing } \\
\text { pattern } \\
M(\mathrm{sd})\end{array}$ \\
\hline$\overline{N=60}$ & $4.02(1.02)$ & $3.70(1.06)$ & $3.60(1.15)$ & $4.18(0.99)$ & $3.78(1.13)$ & $3.77(1.10)$ \\
\hline Novice $N=30$ & $4.43(0.67)$ & $4.07(0.81)$ & $4.00(0.89)$ & $4.53(0.72)$ & $4.00(1.00)$ & $3.90(0.89)$ \\
\hline Experienced $N=30$ & $3.60(1.27)$ & $3.33(1.25)$ & $3.20(1.30)$ & $3.83(1.26)$ & $3.57(1.30)$ & $3.63(1.31)$ \\
\hline
\end{tabular}

Tab. 2 illustrates that the teachers' level of confidence regarding the "Continue a repeating pattern" task is higher than regarding the two other tasks. Moreover, the table indicates that the overall level of confidence of experienced teachers is higher than that of novice teachers, and that their level of confidence about children's percentage of success is higher than their level of confidence regarding children's errors. A significant difference was found between novice and experienced teachers $(t=3.242, p<0.05)$.

\subsection{Results of teachers' pedagogical knowledge of content and students}

Teacher's pedagogical knowledge was examined in relation to the results of the preliminary study. The teachers were requested to address the following questions regarding each task: What would be the percentage of success of children aged 5-6 and of children aged 4-5? What would be the errors children would make?

\subsection{Results of teachers' knowledge about the "Continue a repeating pattern" task}

In the preliminary study, $88.8 \%$ of the children aged $5-6$ and $71 \%$ of the children aged $4-5$ answered the task correctly (as shown in Fig. 5). The teachers were asked to estimate the percentage of children that would succeed in the task (Tab. 3). 
Tab. 3: The percentage of teachers estimating each range of success percentage in the "continue a repeating pattern" task

\begin{tabular}{lcccccc}
\hline & \multicolumn{3}{c}{ Regarding ages 4-5 } & \multicolumn{3}{c}{ Regarding ages 5-6 } \\
\cline { 2 - 6 } & $N=60$ & $\begin{array}{c}N=30 \\
\text { Novice }\end{array}$ & $\begin{array}{c}N=30 \\
\text { Experienced }\end{array}$ & $N=60$ & $\begin{array}{c}N=30 \\
\text { Novice }\end{array}$ & $\begin{array}{c}N=30 \\
\text { Experienced }\end{array}$ \\
\hline $0 \%-20 \%$ & 3.3 & 6.7 & 0.0 & 0.0 & 0.0 & 0.0 \\
$21 \%-40 \%$ & 5.0 & 6.7 & 3.3 & 0.0 & 0.0 & 0.0 \\
$41 \%-60 \%$ & 25.0 & 20.0 & 30.0 & 5.0 & 6.7 & 3.3 \\
$61 \%-80 \%$ & 46.7 & 40.0 & 53.3 & 13.3 & 13.3 & 13.3 \\
$81 \%-100 \%$ & 20.0 & 26.7 & 13.3 & 81.7 & 80.0 & 83.3 \\
\hline
\end{tabular}

The teachers' common estimated percentage of success for children aged 5-6 correlated with the results of the preliminary study. They also predicted correctly the effect of children's age on the percentage of success. However, the teachers, especially the experienced ones, tended to underestimate children aged 4-5: about a third of them thought that fewer children than observed in the preliminary study would succeed. A significant difference was found between novice and experienced teachers' estimations regarding $4-5$ years old children (T-test $2.14, p<0.05$ ).

In the preliminary study, only a single error was observed: the children copied the pattern. When asked to indicate errors that children would make in this task, half of the teachers indicated this error, twenty-five percent pointed out errors that had been mentioned in previous studies but had not been observed in the present study, and the rest did not mention any error (Tab. 4): Almost half of the novice teachers $(43 \%)$ and only a small part of the experienced teachers $(7 \%)$.

Tab. 4: Errors that teachers thought children would make in the "continue a repeating pattern" task

\begin{tabular}{|c|c|c|c|}
\hline The error & $\begin{array}{c}\text { Repeat one } \\
\text { element } \\
\text { systematically: }\end{array}$ & $\begin{array}{l}\text { Continue } \\
\text { randomly }\end{array}$ & $\begin{array}{c}\text { Copy the pattern: } \\
\bigcirc \square \bigcirc \square \bigcirc \square\end{array}$ \\
\hline Was the error reported in other studies? & yes & yes & yes \\
\hline Percentage of children making the error & 0.0 & 0.0 & 19.5 \\
\hline \multicolumn{4}{|c|}{ Percentage of teachers pointing out each error } \\
\hline$N=60$ & 3.3 & 21.7 & 50.0 \\
\hline Novice $N=30$ & 0.0 & 13.3 & 43.3 \\
\hline Experienced $N=30$ & 6.7 & 30.0 & 56.7 \\
\hline Difference: Chi-square value & $4.687^{*}$ & $8.562^{* *}$ & $3.920^{*}$ \\
\hline
\end{tabular}

Note. ${ }^{*}=p<0.05,{ }^{* *}=p<0.01$

\subsection{Results of teachers' knowledge about the "Complete a repeating pattern" task}

The preliminary study showed that $94.4 \%$ of the children aged $5-6$ and $77.8 \%$ of the children aged $4-5$ answered correctly (as shown in Fig. 5).

The teachers were asked to estimate the percentage of children of each group that would succeed in this task (Tab. 5). Results show that they tended to underestimate the children's performance. For each children group, the teachers estimated a lower percentage of success than observed in the preliminary study. Some of the teachers thought that none of the children would succeed in this task.

Tab. 5: The percentage of teachers estimating each range of success percentage in the "complete a repeating pattern" task

\begin{tabular}{|c|c|c|c|c|c|c|}
\hline & \multicolumn{3}{|c|}{$\begin{array}{c}\text { Regarding ages } 4-5 \\
\end{array}$} & \multicolumn{3}{|c|}{ Regarding ages 5-6 } \\
\hline & $\bar{N}=60$ & $\begin{array}{l}N=30 \\
\text { Novice }\end{array}$ & $\begin{array}{c}N=30 \\
\text { Experienced }\end{array}$ & $N=60$ & $\begin{array}{l}N=30 \\
\text { Novice }\end{array}$ & $\begin{array}{c}N=30 \\
\text { Experienced }\end{array}$ \\
\hline $0 \%-20 \%$ & 6.7 & 6.7 & 6.7 & 5.0 & 6.7 & 3.3 \\
\hline $21 \%-40 \%$ & 15.0 & 13.3 & 16.7 & 1.7 & 0.0 & 3.3 \\
\hline $41 \%-60 \%$ & 31.7 & 30.0 & 33.3 & 3.3 & 0.0 & 6.7 \\
\hline $61 \%-80 \%$ & 35.0 & 40.0 & 30.0 & 36.7 & 26.7 & 46.7 \\
\hline $81 \%-100 \%$ & 11.7 & 10.0 & 13.3 & 53.3 & 66.7 & 40.0 \\
\hline
\end{tabular}


Contrary to the results of the preliminary study, the teachers estimated that the percentage of success in the "complete a repeating pattern" task would be lower than in the "continue a repeating pattern" task. A significant difference was found between novice and experienced teachers' estimations regarding $5-6$ years old children (T-test $-3.94, p<0.01$ ).

In the preliminary study, two errors were observed. The most common error was completing the pattern by copying its left side. When asked to indicate errors that children would make in this task, all the teachers pointed out the same errors as for the "continue a repeating pattern" task (see Tab. 4). Most of the experienced teachers mentioned at least one error, though some of the errors they indicated had not been observed in the preliminary study (such as the error of continuing persistently with one shape). Almost half of the novice teachers did not mention any errors.

\subsection{Results of teachers' knowledge about the "Continue a growing pattern" task}

In the preliminary study, the percentage of success of both children groups was low: only $7.5 \%$ of the children aged 5-6 and 3\% of the children aged 4-5 answered correctly (as shown in Fig. 5). No significant difference was found between the two children groups. The teachers were asked to estimate what the children's percentage of success would be (Tab. 6).

Tab. 6: The percentage of teachers estimating each range of success percentage in the "continue a growing pattern" task

\begin{tabular}{lrrrrrr}
\hline & \multicolumn{3}{c}{ Regarding ages $4-5$} & \multicolumn{3}{c}{ Regarding ages 5-6 } \\
\cline { 2 - 7 } & $N=60$ & \multicolumn{1}{c}{$\begin{array}{c}N=30 \\
\text { Novice }\end{array}$} & $\begin{array}{c}N=30 \\
\text { Experienced }\end{array}$ & $N=60$ & $\begin{array}{c}N=30 \\
\text { Novice }\end{array}$ & $\begin{array}{c}N=30 \\
\text { Experienced }\end{array}$ \\
\hline $0 \%-20 \%$ & 83.3 & 100.0 & 66.7 & 30.0 & 36.7 & 23.3 \\
$21 \%-40 \%$ & 10.0 & 0.0 & 20.0 & 21.7 & 13.3 & 30.0 \\
$41 \%-60 \%$ & 6.7 & 0.0 & 13.3 & 40.0 & 43.3 & 36.7 \\
$61 \%-80 \%$ & 0.0 & 0.0 & 0.0 & 8.3 & 6.7 & 10.0 \\
$81 \%-100 \%$ & 0.0 & 0.0 & 0.0 & 0.0 & 0.0 & 0.0 \\
\hline
\end{tabular}

The teachers estimated correctly that continuing a growing pattern would be more difficult for children than continuing or completing a repeating pattern. Accordingly, they predicted that the percentage of success in this task would be much lower than in the previous tasks (see Tab. 3, 5). However, the teachers, especially the experienced ones, overestimated the children's performance. A significant difference was found between novice and experienced teachers' estimations regarding both children groups: 5-6 years old children (T-test 2.71, $p<0.01$ ), and $4-5$ years old children (T-test $9.68, p<0.01$ ).

In the preliminary study, the children made various errors when solving this task. The teachers indicated most of them, as well as an error that had not been observed - random continuation (Tab. 7). However, they did not indicate the most common error - copying the pattern either from left to right or from right to left.

Tab. 7: Errors that teachers thought children would make in the "continue a growing pattern" task

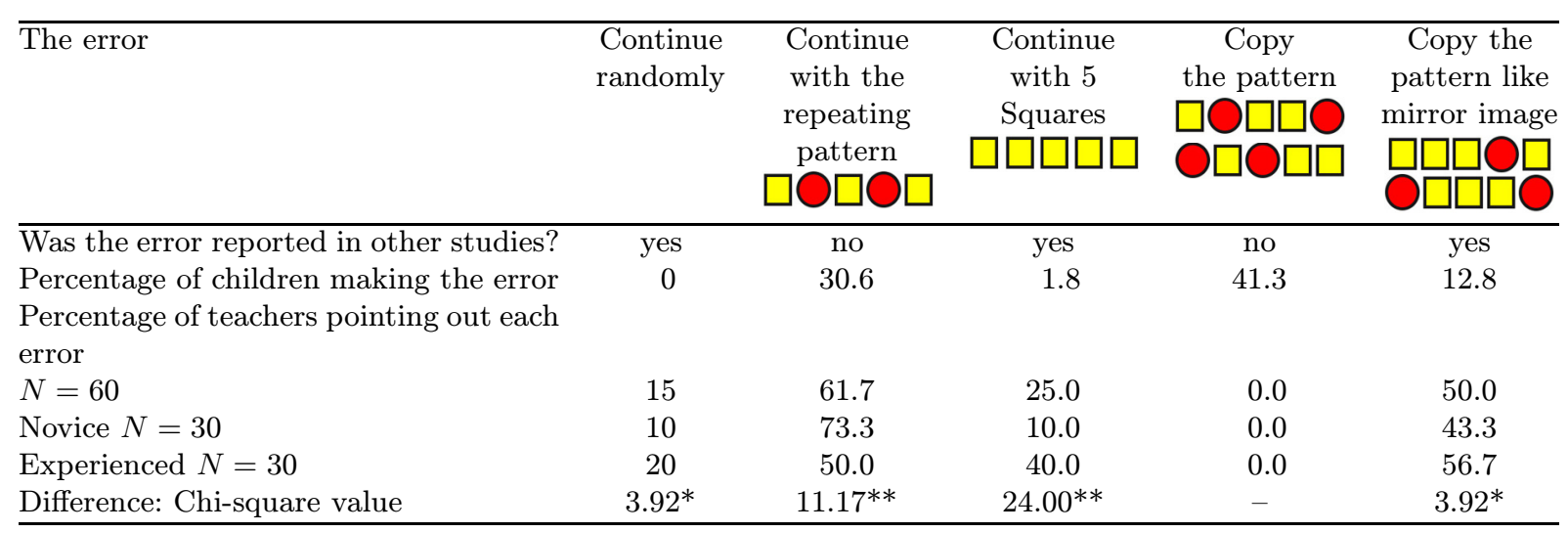

Note. $-=$ no significant difference, ${ }^{*}=p<0.05,{ }^{* *}=p<0.01$ 
The results in Tab. 7 show differences between the percentage of teachers who indicated a certain error and the percentage of children who had made it in the study. Errors were pointed out in a higher or lower percentage than had been observed. For example, the error of continuing the growing pattern with a repeating pattern was observed in a lower percentage $(32 \%)$ than the teachers thought $(62 \%)$. Experienced teachers tended to indicate this error more and in a higher percentage than did novice teachers. In this task, all of the experienced teachers and most of the novice teachers pointed out at least one error. Some experienced teachers indicated more than one error, so the total percentage for each error in Tab. 7 can exceed $100 \%$.

\section{Discussion and conclusions}

The present study investigates the pedagogical knowledge of kindergarten teachers regarding patterns. It focuses on teachers' knowledge of content and students - a component of knowledge that was not studied enough in past studies and is considered an important component of knowledge (e.g. Lee, 2010): a teacher who knows what is easy or difficult for his students, and knows what the common errors of students are, can choose the suitable tasks for developing students' knowledge; can focus his explanations and promote students' mathematical thinking. Knowledge of content and students improves the quality and precision of the teaching process: teachers who know typical errors and the reasons that cause them may include discussions of these errors while teaching - thus deepening children's understanding. Also, teachers that don't know what is easy or difficult for children may avoid teaching thought-provoking tasks that may help deepen children's understanding of the material only because they think it too difficult; or teach tasks that they think are easy but in fact are too difficult for children, thus frustrating them.

The findings of the present study support this approach and emphasize the importance of teachers' knowledge about students.

The study also investigates teachers' self-efficacy regarding their knowledge about students. Selfefficacy is an important factor in the teaching-learning process (e.g. Dellinger et al., 2008). The findings of the present study show that the teachers were more confident when they were more knowledgeable and least confident regarding the pattern type or task they were less knowledgeable about. A comparison between novice and experienced teachers was conducted. The findings support previous studies and show that novice teachers are less confident and less knowledgeable than experienced teachers.

The present study illustrated several main findings that may have implications for teachers' training and guidance.

The results of pedagogical knowledge regarding children's typical answers and errors show gaps in teachers' knowledge. First, they failed to predict the most common error that children had made copying the pattern: half of the teachers didn't mention it in the repeating pattern tasks, and all of the teachers didn't mention it in the growing pattern task. This error was observed in previous studies (e.g. Fox, 2005a; Garrick et al., 1999) and in the preliminary study of the current research. This error implies that the method that many children use for solving pattern tasks is copying, instead of identifying the structure or generalizing. Although children can succeed in continuing repeating patterns by using a procedural or rhythmic approach (Threlfall, 1999), it is important that teachers draw students' attention to regularity and sequencing. Only in this way, repeating patterns may form the basis for generalization and algebraic thinking. The fact that the teachers did not predict this error suggests that they are not aware that children use an algorithm and that maybe they do not put enough emphasis on the structure of the pattern during the teaching process. The results emphasize the importance of the pedagogical knowledge of content and students: by knowing children's errors, teachers may focus their explanations and promote children's knowledge and thinking abilities.

Apart from copying the pattern, the children made other errors, most of which were indicated by the teachers, both responses which had been reported in previous studies and responses which had not. It can be assumed that the teachers relied on various children's answers they had observed in the course of their work. The results emphasize the importance of learning from teachers' practical experience and from what they observe during their work in the kindergarten (Jacobs et al., 2010; Cohen \& Ball, 1990).

The results of pedagogical knowledge of what is easy or difficult for children show a significant difference between teachers' estimation of children's performance and the actual percentage of success.

Regarding the repeating pattern tasks, in the preliminary study, the percentage of children's success in the completing a repeating pattern task was very similar to, and even slightly higher than, in the continuing a repeating pattern task. Previous studies (Warren, 2005; Warren \& Miller, 2010) were inconclusive about what is easier for children - to complete or to continue a pattern. In the present study, teachers assumed incorrectly that completing the pattern would be much more difficult. The results also illustrate that teachers, especially the experienced ones, tended to underestimate children's performance. 
They failed to assess the difficulty level of the tasks, even though they were used to teach repeating patterns. It is possible that when the teachers referred to the "continue a repeating pattern" task, their attention was directed to various tasks given in the kindergarten, and not necessarily to the specific task on which the present study focuses. The underestimation was most prominent in the case of $4-5$ years old children in the "complete a repeating pattern" task, in which the children performed best. The participating teachers reported they were reluctant to teach this task in kindergarten because they believed it was difficult. It is important to present different tasks of patterns to kindergarten children at different levels of difficulty. The results demonstrate that teachers do not do this enough and that they should be educated and guided to do so.

Regarding the growing pattern task, in the preliminary study, the percentage of children's success in the growing pattern task was much lower than in the repeating pattern tasks. Previous studies (e.g. Warren, 2005) also indicate that growing patterns are more difficult for children. However, the teachers tended to overestimate children's performance. It may be due to their lack of experience in teaching this type of pattern. In the preliminary study, there was no difference between children aged $4-5$ and children aged 5-6 in this task, meaning that even if it was their second year in the kindergarten, the children failed to solve this task which they had not encountered before. The fact that the children were more knowledgeable about a pattern type they had previously studied emphasize the importance of the teaching-learning process, leading to a recommendation to teach growing patterns in kindergartens.

Overall, the results illustrate that teachers' knowledge of content and students is insufficient and should be reinforced.

In line with previous findings (e.g. Leinhardt, 1989) results regarding knowledge and seniority indicate that experienced teachers have a wider pedagogical knowledge than novice teachers. It is reasonable to assume that experienced teachers would have greater knowledge than novice teachers, due to their long acquaintance with children.

Results regarding the levels of self-efficacy show that teachers are more confident in their knowledge regarding repeating patterns than regarding growing patterns, possibly because of their lack of experience in teaching growing patterns. The results also show that experienced teachers have a higher sense of self-efficacy than novice teachers, perhaps due to their longer acquaintance with children's responses to patterning tasks. The results support previous findings indicating a correlation between seniority and selfefficacy (Chiu \& Klassen, 2010), and emphasize the need to guide and instruct all teachers, particularly novice, in a professional manner during their work in the kindergarten.

The present study has three main limitations. The first limitation is that the research results do not link teachers' knowledge and the children's attainments. The second resides in the fact that the study does not explore other components of knowledge that teachers need, such as subject matter knowledge or knowledge of content and teaching. The third limitation is methodological: in the study three tasks were examined and for generalizing more tasks are needed.

Hence, it is recommended conducting a further study of the level of teachers' various components of knowledge and to explore possible relations between teachers' knowledge and the attainments of the children in their kindergarten.

\section{Acknowledgment}

The study is part of a doctoral thesis conducted under the supervision of Prof. Pessia Tsamir and Prof. Dina Tirosh, TAU, Israel.

\section{References}

Ball, D. L., Thames, M. H., \& Phelps, G. (2008). Content knowledge for teaching - What makes it special? Journal of Teacher Education, 59(5), 389-407. https://doi.org/10.1177/0022487108324554

Ball, D. L., \& Wilson, S. M. (1990). Knowing the subject and learning to teach it: Examining assumptions about becoming a mathematics teacher. National Center for Research on Teacher Education, Michigan State University.

Bandura, A. (1977). Self-efficacy: Toward a unifying theory of behavioral change. Psychological Review, 84(2), 191-215. https://doi.org/10.1037/0033-295X.84.2.191

Bandura, A. (1986). Social foundations of thought and action: A social cognitive. Englewood Cliffs, NJ: Prentice-Hall. https://doi.org/10.1017/S0813483900008238

Brouwers, A., \& Tomic, W. (2000). A longitudinal study of teacher burnout and perceived self- efficacy in classroom management. Teacher and Teaching Education, 16(2), 239-253.

https://doi.org/10.1016/S0742-051X(99)00057-8 
Burton, G. M. (1982). Patterning: Powerful play. School Science and Mathematics, 82(1), 38-44.

https://doi.org/10.1111/j.1949-8594.1982.tb17161.x

Chiu, M., \& Klassen, R. M. (2010). Effects on teachers' self-efficacy and job satisfaction: Teacher gender, years of experience and job stress. Journal of Educational Psychology, 102(3), 741-756. https://doi.org/10.1037/a0019237

Clements, D. H. (2001). Mathematics in the preschool. Teaching Children Mathematics, 7(5), 270-275.

Clements, D. H., \& Sarama, J. (2007). Effects of a preschool mathematics curriculum: Summative research on the Building Blocks Project. Journal for Research in Mathematics Education, 38(2), 136-163.

Clements, D. H., \& Sarama, J. (2011). Early childhood mathematics intervention. Science, 333(6045), 968-970. https://doi.org/10.1126/science.1204537

Cohen, D. K., \& Ball, D. L. (1990). Relations between policy and practice: a commentary. Educational Policy and Analysis, 12(3), 331-338. https://doi.org/10.3102/01623737012003331

Dellinger, A., Bobbett, J., Olivier, D., \& Ellett, C. (2008). Measuring teachers' self-efficacy beliefs: Development and use of the TEBS-Self. Teaching and Teacher Education, 24(3), 751-766.

https://doi.org/10.1016/j.tate.2007.02.010

Economopoulos, K. (1998). What comes next? The mathematics of pattern in kindergarten. Teaching Children Mathematics, 5(4), 230-233.

Fox, J. (2005a). Connecting algebraic development to mathematical patterning in early childhood. In P. Grootenboer., R. Zevenbergen, \& M. Chinnappan (Eds.), Proceedings of the 29th Annual Conference of the Mathematics Education Research Group of Australia (Vol. 1, pp. 221-228). MERGA.

Fox, J. (2005b). Child initiated mathematical patterning in the pre-compulsory years. In H. L. Chick, \& J. L. Vincent (Eds.), Proceedings of the $29^{\text {th }}$ International Conference for the Psychology of Mathematics Education (2, pp. 313-320). PME.

Garrick, R., Threlfall, J., \& Orton, A. (1999). Pattern in the nursery. In A. Orton (Ed.), Pattern in the teaching and learning of mathematics (pp. 1-17). Cassel.

Gibbs, W. (1999). Pattern in the classroom. In A. Orton (Ed.), Pattern in the teaching and learning of mathematics (pp. 207-221). Cassel.

Greenes, C., Ginsburg, H. P., \& Balfanz, R. (2004). Big mathematics for little kids. Early Childhood Research Quarterly, 19(1), 159-166. https://doi.org/10.1016/j.ecresq.2004.01.010

Guo, Y., Justice, L. M., Sawyer, B., \& Tompkins, V. (2011). Exploring factors related to preschool teachers' self-efficacy. Teaching and Teacher Education, 27(5), 961-968. https://doi.org/10.1016/j.tate.2011.03.008

Hackett, G., \& Betz, N. (1989). An exploration of the mathematics self-efficacy/mathematics performance correspondence. Journal for Research in Mathematics Education, 20(3), 261-273. https://doi.org/10.2307/749515

Hill, H. C., Ball, D. L., \& Schilling, S. G. (2008). Unpacking pedagogical concept knowledge: Conceptualizing and measuring teachers' topic-specific knowledge for students. Journal for Research in Mathematics Education, $39(4), 372-400$.

Jacobs, R. V., Lamb, L. C., \& Philip, R. A. (2010). Professional noticing of children's mathematical thinking. Journal for Research in Mathematics Education, 41(2), 169-202.

Kyriakides, L., \& Gagatsis, A. (2003). Assessing student problem solving skills. Structural Equation Modeling, 10(4), 609-621. https://doi.org/10.1207/S15328007SEM1004_7

Krauss, S., Baumert, J., \& Blum, W. (2008). Secondary mathematics teachers' pedagogical content knowledge and content knowledge: Validation of the COACTIV constructs. ZDM, 40(5), 873-892.

https://doi.org/10.1007/s11858-008-0141-9

Lee, J. (2010). Exploring kindergarten teachers' pedagogical content knowledge of mathematics. International Journal of Early Childhood, 42(1), 27-41. https://doi.org/10.1007/s13158-010-0003-9

Leinhardt, G. (1989). Math lessons: a contrast of novice and expert competence. Journal for Research in Mathematics Education, 20(1), 52-75. https://doi.org/10.2307/749098

McCray, J. S., \& Chen, J. Q. (2012). Pedagogical content knowledge for preschool mathematics: Construct validity of a new teacher interview. Journal of Research in Childhood Education, 26(3), 291-307. https://doi.org/10.1080/02568543.2012.685123

Midgley, C., Feldlaufer, H., \& Eccles, J. S. (1989). Change in teacher efficacy and student self and task-related beliefs in mathematics during the transition to junior high school. Journal of Educational Psychology, 81(2), 247-258. https://doi.org/10.1037/0022-0663.81.2.247 
Moss, J., \& Beatty, R. (2006). Knowledge building and knowledge forum: grade 4 students collaborate to solve linear generalization problems. In J. Novotná, H. Moraová, M. Krátká, \& N. Stehlíková (Eds.), Proceedings of the $30^{\text {th }}$ Conference of the International Group for the Psychology of Mathematics Education

(Vol. 4, pp. 193-199). PME.

Mulligan, J. T., Prescott, A., \& Mitchelmore, M. C. (2004). Children's development of Structure in early mathematics. In Proceedings of the $28^{\text {th }}$ PME International Conference (Vol. 3, pp. 393-401). Bergen University College.

Ministry of Education in Israel. (2010). Curriculum for mathematics in kindergarten. Ministry of Education, Israel. [Hebrew]

National Council of Teachers of Mathematics. (1989). Curriculum and Evaluation for school mathematics. NCTM USA.

National Council of Teachers of Mathematics. (2000). Principles and Standards for school mathematics. NCTM USA.

Papic, M., \& Mulligan, J. (2007). The growth of early mathematical patterning: an intervention study. In J. Watson, \& K. Beswick (Eds.), Proceedings of the $30^{\text {th }}$ Annual Conference of the Mathematical Education Research Group of Australia (Vol. 2, pp. 591-600). MERGA.

Papic, M., Mulligan, J., \& Mitchelmore, M. (2011). Assessing the development of preschoolers' mathematical patterning. Journal for Research in Mathematics Education, 42(3), 237-269.

https://doi.org/10.5951/jresematheduc.42.3.0237

Shulman, L. S. (1986). Those who understand: knowledge growth in teaching. Educational Researcher, 15(2), 4-14. https://doi.org/10.3102/0013189X015002004

Shulman, L.S. (1987). Knowledge and teaching: Foundations of the new reform. Harvard Educational Review, 57(1), 1-21. https://doi.org/10.17763/haer.57.1.j463w79r56455411

Starkey, P., Klein, A., \& Wakeley, A. (2004). Enhancing young children's mathematical knowledge through a pre-kindergarten mathematics intervention. Early Childhood Research Quarterly, 19(1), 99-120. https://doi.org/10.1016/j.ecresq.2004.01.002

Tchoshanov, M. A. (2011). Relationship between teacher knowledge of concepts and connections, teaching practice and student achievement in middle grades mathematics. Educational Studies in Mathematics, 76(2), 141-164. https://doi.org/10.1007/s10649-010-9269-y

Threlfall, J. (1999). Repeating pattern in the early primary years. In A. Orton (Ed.), Pattern in the teaching and learning of mathematics (pp. 18-29). Cassel.

Tirosh, D., Even, R., \& Robinson, N. (1998). Simplifying algebraic expressions: Teacher awareness and teaching approaches. Educational Studies in Mathematics, 35(1), 51-64. https://doi.org/10.1023/A:1003011913153

Tschannen-Moran, M., \& Woolfolk-Hoy, A. (2007). The differential antecedents of self-efficacy beliefs of novice and experienced teachers. Teaching and Teacher Education, 23(6), 944-956.

https://doi.org/10.1016/j.tate.2006.05.003

Warren, E. (2005). Patterns supporting the development of early algebraic thinking. In P. Clarkson, A. Downton, D. Gronn, M. Horne, A. McDonough, R. Pierce, \& A. Roche (Eds.), Proceedings of the 28th annual conference of the Mathematics Education Research Group of Australasia, Melbourne (Vol. 1, pp. 759-766). MERGA.

Warren, E., \& Miller, J. (2010). Indigenous children's ability to pattern as they enter kindergarten/pre-prep settings: an exploratory study. In L. Sparrow, B. Kissane, \& C. Hurst (Eds.), Proceedings of the 33rd annual conference of the Mathematics Education Research Group of Australasia (pp. 594-601). MERGA.

Waters, J. (2007). Mathematical patterning in early childhood settings. In J. Watson, \& K. Beswick (Eds.), Proceeding of the $30^{\text {th }}$ Annual Conference of the Mathematical Education Research Group of Australia (Vol. 2, pp. 565-572). MERGA.

Zazkis, R., \& Liljedahl, P. (2002). Generalization of patterns: the tension between algebraic thinking and algebraic notation. Educational Studies in Mathematics, 49(3), 379-402.

https://doi.org/10.1023/A:1020291317178

Zhang, Y. (2015). Pedagogical content knowledge in early mathematics: What teachers know and how it associates with teaching and learning. A dissertation submitted for the degree of Ph.D. Loyola University, USA. 